\title{
Cancer-Associated Fibroblasts as Players in Cancer Development and Progression and Their Role in Targeted Radionuclide Imaging and Therapy
}

\author{
Sofia Koustoulidou ${ }^{1}$ * , Mark W. H. Hoorens ${ }^{1}$, Simone U. Dalm ${ }^{1}$, Shweta Mahajan ${ }^{2}$, Reno Debets ${ }^{2}$, \\ Yann Seimbille ${ }^{1} \mathbb{D}$ and Marion de Jong ${ }^{1}$ \\ 1 Department of Radiology and Nuclear Medicine, Erasmus University Medical Center, Dr. Molewaterplein 40, \\ 3015 GD Rotterdam, The Netherlands; m.hoorens@erasmusmc.nl (M.W.H.H.); s.dalm@erasmusmc.nl (S.U.D.); \\ y.seimbille@erasmusmc.nl (Y.S.); m.hendriks-dejong@erasmusmc.nl (M.d.J.) \\ 2 Department of Medical Oncology, Erasmus University Medical Center, Dr. Molewaterplein 40, \\ 3015 GD Rotterdam, The Netherlands; j.debets@erasmusmc.nl (R.D.); s.mahajan@erasmusmc.nl (S.M.) \\ * Correspondence: s.koustoulidou@erasmusmc.nl
}

check for updates

Citation: Koustoulidou, S.; Hoorens, M.W.H.; Dalm, S.U.; Mahajan, S.; Debets, R.; Seimbille, Y.; de Jong, M. Cancer-Associated Fibroblasts as Players in Cancer Development and Progression and Their Role in Targeted Radionuclide Imaging and Therapy. Cancers 2021, 13, 1100. https://doi.org/10.3390/ cancers 13051100

Academic Editors:

Vladimir Tolmachev and Anzhelika Vorobyeva

Received: 4 February 2021

Accepted: 20 February 2021

Published: 4 March 2021

Publisher's Note: MDPI stays neutral with regard to jurisdictional claims in published maps and institutional affiliations.

Copyright: (c) 2021 by the authors. Licensee MDPI, Basel, Switzerland. This article is an open access article distributed under the terms and conditions of the Creative Commons Attribution (CC BY) license (https:/ / creativecommons.org/licenses/by/ $4.0 /)$.
Simple Summary: The tumour microenvironment contains a unique population of cells, of complex origin and diverse functionality, known as Cancer associated fibroblasts (CAFs). In recent years there has been a growing interest in targeting CAFs to aid cancer diagnosis and therapy. Amongst the approaches utilized so far, targeting Fibroblast activation protein (FAP) has shown a lot of promise. In this review, we will focus on our current knowledge of the biology of CAFs as well as theranostic applications that will enhance cancer diagnosis and therapy in cancers carrying a distinct CAF signature.

Abstract: Cancer Associated Fibroblasts (CAFs) form a major component of the tumour microenvironment, they have a complex origin and execute diverse functions in tumour development and progression. As such, CAFs constitute an attractive target for novel therapeutic interventions that will aid both diagnosis and treatment of various cancers. There are, however, a few limitations in reaching successful translation of CAF targeted interventions from bench to bedside. Several approaches targeting CAFs have been investigated so far and a few CAF-targeting tracers have successfully been developed and applied. This includes tracers targeting Fibroblast Activation Protein (FAP) on CAFs. A number of FAP-targeting tracers have shown great promise in the clinic. In this review, we summarize our current knowledge of the functional heterogeneity and biology of CAFs in cancer. Moreover, we highlight the latest developments towards theranostic applications that will help tumour characterization, radioligand therapy and staging in cancers with a distinct CAF population.

Keywords: CAFs; FAP; theranostics; radionuclide therapy

\section{Introduction}

Cancer remains the second leading cause of death in the world [1], despite major improvements in diagnosis and therapy. This is partly because most of the developed therapeutics are targeting tumour cells ignoring however the surrounding tumour microenvironment (TME) [2]. The role of TME in cancer development has only gained attention in the recent years, driving research towards a new cancer treatment paradigm: the TME.

The TME may consist of more than $50 \%$ of the tumour mass and together with tumour cells it coordinates rapid proliferation, local invasion and eventually metastasis to the surrounding tissues [3]. In addition to cancer cells, the TME comprises immune cells, tumour vasculature, fibroblasts, extracellular matrix (ECM), myofibroblasts, neuroendocrine cells and adipose cells [4]. Intracellular communication is directed by a very complex network of cytokines, chemokines, inflammatory and matrix remodelling enzymes; the TME presents in fact similarities to the processes described in wound healing and inflammation. 
TME-specific markers, found during tumour development, can be useful not only to understand the composition of TME, but also to aid diagnosis and therapy strategies [5]. It has been shown that spatial distribution of immune cells is positively correlated to patient survival in multiple tumour types (e.g., breast cancer and colorectal cancer) [6]. There are however, additional cell types within the TME that can regulate and affect oncogenesis. In particular, a subpopulation of fibroblasts called cancer associated fibroblasts (CAFs). These cells often constitute a major component in the TME, creating the "ground" in which the tumour cells can grow [7].

Growing evidence proves that CAFs can stimulate a malignant tumour phenotype due to their heterogeneous nature and functional diversity. Others suggest that a distinct CAF subpopulation, known as myofibroblasts (myCAFs), can have a more tumour-restraining role [8]. It is therefore, necessary to evaluate the importance of CAF biology and its various functions in cancer to identify specific subsets of the CAF populations that could constitute a springboard for more precise treatments. In this review, we aim to summarize the current understanding of the origin, and functional heterogeneity of CAFs in tumour development and progression. In addition, we outline potential strategies that target CAFs for their use in radionuclide imaging and therapy.

\section{Cancer Associated Fibroblasts (CAFs)}

Under normal conditions, fibroblasts are quiescent spindle shaped cells located in the connective tissue of most organs. They regulate the polarity and function of normal epithelium by generating the basement membrane. During tissue fibrosis and wound healing, these same fibroblasts are transformed into smooth muscle reactive fibroblasts and contribute to tissue repair [9]. The assumption that a tumour is a 'wound that does not heal' [10], has led to great interest in CAFs and their potential use in cancer therapy.

Studies have shown that CAFs are responsible for the synthesis and remodelling of the ECM and play various roles in cancer metastasis, angiogenesis, and drug resistance. Even though extensively studied in vitro, the CAF population remains largely uncharacterized in regards to its origin, biology, and subtypes [11], presenting phenotypic heterogeneity and functional diversity [12].

\section{Origins of CAFs}

A number of different tissue types are responsible for the origin of CAFs (Figure 1), highlighting the heterogeneity of this specific cell population. CAFs can be produced from normal tissue fibroblasts that are activated by nearby tumour cells. This activation is strongly dependent on stimuli such as hypoxia, oxidative stress and growth factors produced by neighbouring tumour and immune cells [13]. More specifically, activation via the transforming growth factor- $\beta$ (TGF- $\beta$ ), epidermal growth factor (EGF), platelet-derived growth factor (PDGF), and fibroblast growth factor 2 (FGF2), are the main contributors to fibroblast recruitment $[14,15]$.

The best-studied cell population of CAF origin consist of mesenchymal stem cells (MSCs). In vitro and in vivo studies have provided evidence that MSCs from bone marrow (BM-MSCs) can differentiate into a CAF subtype in tumours such as gliomas, breast, and pancreatic cancers [16,17].

In addition to the adjacent sources, a number of CAFs can be identified from a non-fibroblastic origin. Such cells can be epithelial or endothelial cells, through epithelialto-mesenchymal transition (EMT) or endothelial to mesenchymal transition (EndMT), respectively. The latter transition, was first observed during heart formation where an exchange in TGF- $\beta$ signalling from endothelial to fibroblast-like cells was identified in cardiac tissues, suggesting that a similar phenomenon occurs in cancer tissues [18]. During this process loss of endothelial markers (e.g., CD31) and expression of mesenchymal markers (e.g., fibroblast specific protein (FSP) and $\alpha$-smooth muscle actin ( $\alpha$-SMA)) is often visible. 


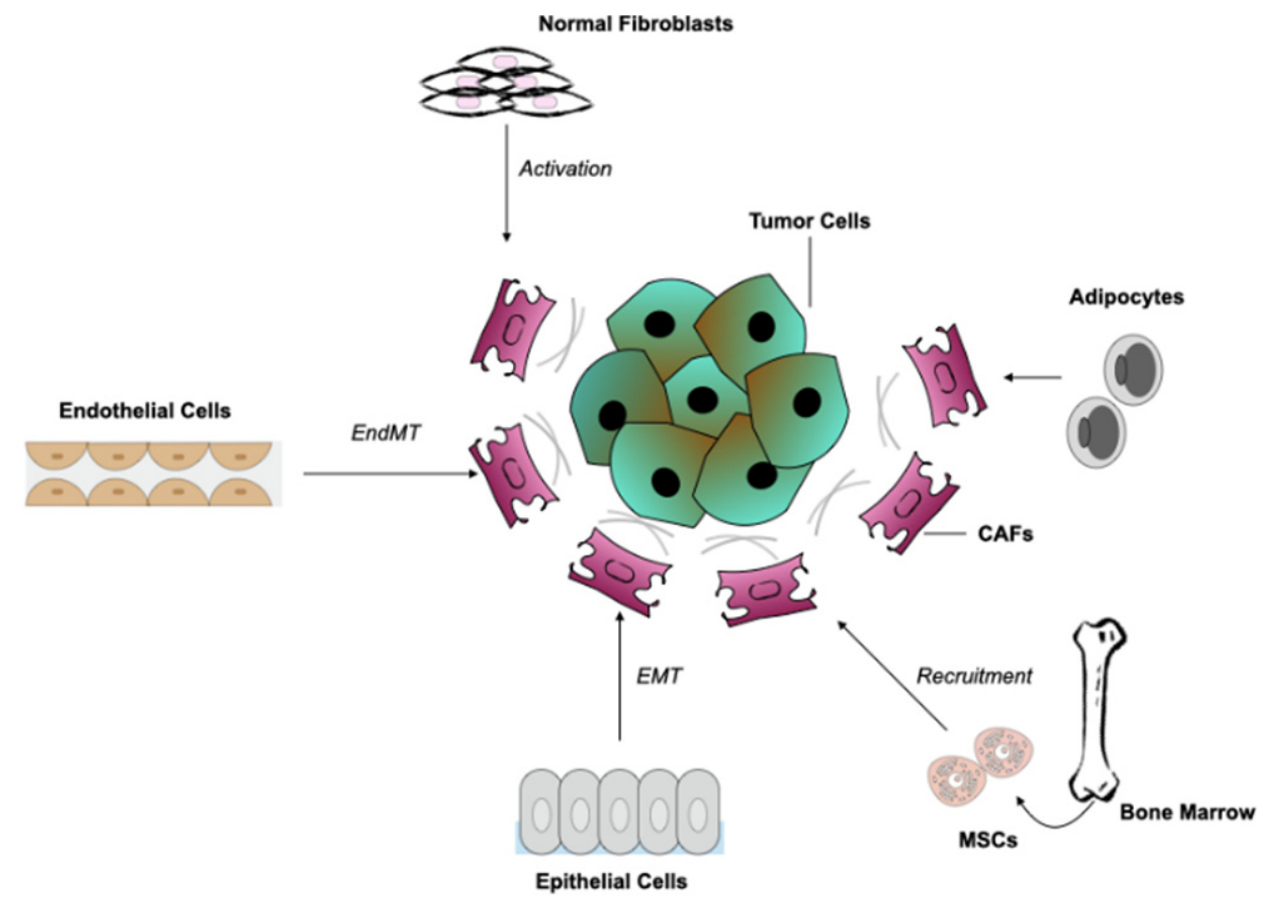

Figure 1. Potential cellular sources for cancer associated fibroblasts (CAFs). Several cellular types might yield CAFs in the TME. This includes normal fibroblasts through activation, recruitment and differentiation of bone marrow-derived mesenchymal stem cells (MSCs); epithelial cells through epithelial-to-mesenchymal transition (EMT) and endothelial cells through endothelialto-mesenchymal transition (EndMT). Another source could be adipocytes through upregulated expression of mesenchymal bone marrow lineage-committed markers.

Adipocytes can also transform into fibroblasts through expression of mesenchymal bone marrow lineage-committed markers (e.g., transcription factor (SOX9), peroxisome proliferator activated receptor- $\gamma(\operatorname{PPAR} \gamma))$ [15]. Adipocytes are located next to cancer cells and due to their interaction with tumour cells, they have become of major interest [19]. Moreover, an adipocyte-like cell population recruited from the bone marrow, known as fibrocytes, settles in the tumour stroma and is considered a subset of CAFs [20].

The difficulty of recognizing CAFs and their origin, lies in the absence of specific markers, although markers that are not expressed in normal cells can be used as an indicator, such as the aforementioned $\alpha$-SMA [9]. Another way to distinguish them from other cells is by exclusion criteria based on their morphological characteristics (e.g., spindle shape characteristics) and the absence of non-mesenchymal markers [21]. In analysing tissue biopsies for example, cells not carrying epithelial, endothelial, and leukocyte markers, having elongated morphology and no mutations associated with cancer cells, can be considered CAFs. Taking into account the latter characteristic, cancer cells undergoing EMT can be also excluded. However, gaining a better understanding of the origin of this cell type and the various subsets could help to identify markers and ways to target these cells and their function.

\section{Functions of CAFs}

Several studies utilizing cell culture as well as in vivo experiments in mouse models, have suggested a diverse number of functions that CAFs might employ. In their study, Olumi et al. were among the first to show that CAFs promote tumour growth in a prostate cancer mouse xenograft model while normal fibroblasts have more inhibitory properties [22]. In addition to tumour growth-promoting function of CAFs, the authors also described involvement in angiogenesis, tumour cell proliferation and metastasis, shedding 
light on the contribution of these cells towards malignant progression. In this section, we will refer to each of these functions separately (Figure 2).

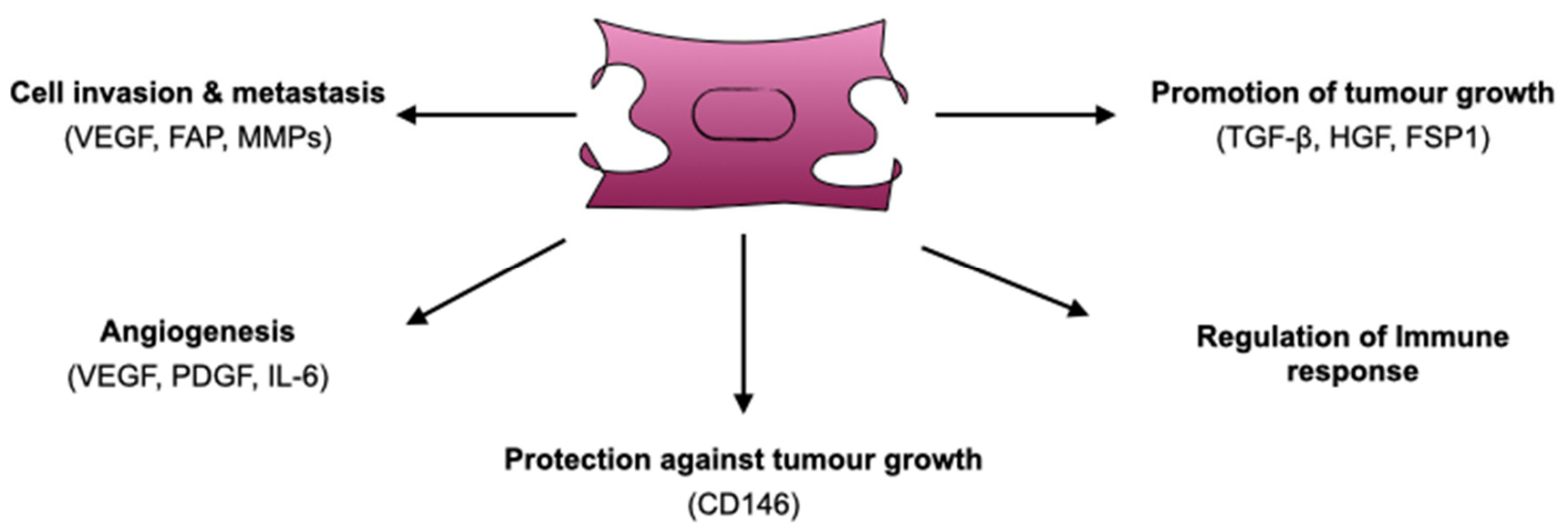

Figure 2. Diverse functions of CAFs: promotion of tumour growth, angiogenesis, cell invasion and metastasis to surrounding tissues, regulation of innate and adaptive immune responses. In addition to tumour-protective roles, CAFs occasionally have anti-tumorigenic functions. VEGF: Vascular Endothelial Growth Factor, FAP: Fibroblast Activation Protein, MMPs: Matrix Metalloproteinases, PDGF: Platelet-Derived Growth Factor, IL-6: Interleukin 6, CD146: Cluster of Differentiation 146, HGF: Hepatocyte Growth Factor, FSP1: Fibroblast-specific Protein 1.

\subsection{Promotion of Tumour Growth}

It is well known that tumour growth depends on the uncontrollable proliferation of tumour cells [23]. This rapid phenomenon can cause changes in the TME and besides stromal cells, CAFs have also been reported to cause induction of tumorigenesis through secretion of various growth factors and cytokines affecting the neighbouring cancer cells [24]. For example, overexpression of growth factor TGF $\beta$ and hepatocyte growth factor (HGF) in mouse fibroblasts was shown to induce breast cancer when co-injected with normal epithelium [25]. In another study, Grum-Schwensen and coworkers showed that Fibroblastspecific protein 1 (FSP1) knockout mice transplanted with cancer cells were less likely to form tumours when compared to mice injected with fibroblasts overexpressing FSP1. The evidence suggested that FSP1 secreted by CAFs alters the TME and thereby enhances cancer progression [26]. In a different example, expression of $\mathrm{N}$-cadherin in melanoma cells allows interaction with $\mathrm{N}$-cadherin-expressing fibroblasts to mediate cell adhesion and to improve the ability of melanoma cells to migrate through stroma and towards the vasculature. This expression of $\mathrm{N}$-cadherin in fibroblasts during melanoma development not only provides adhesion ground to melanoma cells, but also promotes survival hence establishing a highly proliferative and malignant phenotype [27].

Reactive oxygen species (ROS) can modulate metabolic reprogramming of cancer cells but also of CAFs, thus supporting the acclimatization to oxidative stress that initiates CAF differentiation and tumorigenesis. Generation of ROS can trigger the initiation of events associated with metabolic switch in both cancer and CAF development. More specifically, production of hydrogen peroxide $\left(\mathrm{H}_{2} \mathrm{O}_{2}\right)$ by cancer cells initiates oxidative stress in CAFs, followed by reduction of mitochondrial function, increase of glucose uptake and ROS levels, and finally leads to CAF differentiation. As a result, a reactive TME is generated by ROS, where CAFs sustain the energy needed for cancer cell proliferation $[28,29]$. Such environmental changes, and in particular increased $\mathrm{H}_{2} \mathrm{O}_{2}$ levels, can act as markers for therapeutic interventions [30].

\subsection{Protection Against Tumour Growth}

Notably, tumour-protective functions of CAFs have been also reported despite their potent role in tumorigenesis. In a mouse model of pancreatic ductal adenocarcinoma (PDAC), depletion of hedgehog signalling caused reduced stromal content, a more ag- 
gressive tumour phenotype and decreased survival [31]. The hypothesis was that the hedgehog-activated stroma prevents tumour angiogenesis and blocks tumour growth. In a different study, Brechbuhl et al. suggested that CAFs can affect oestrogen receptor (ER) expression and growth dependency in luminal breast cancer. In particular, breast cancer fibroblasts carrying a CD146-positive phenotype, may represent a subset of CAFs, which might confer oestrogen-dependent tumour cell proliferation and sensitivity to tamoxifen treatment [32].

\subsection{Cell Invasion and Metastasis}

In addition to promoting tumour growth, CAFs are also capable of rendering cells to invade surrounding tissues through cell-to-cell interactions and secretion of different invasive molecules (e.g., cytokines, chemokines, inflammatory molecules), hence, modifying the adjacent ECM [29]. The migration into the ECM is known to be a prerequisite for cancer cells to intravasate and ultimately metastasize [33]. In their study, Fukumura and coworkers used GFP transgenic mice under the control of the VEGF promoter and showed that CAFs positive for GFP were infiltrating tumour regions; however, it was difficult to assess whether it was CAFs contributing to this infiltration or the epithelial cells themselves [34]. One hypothesis was that CAFs may support the migration of cancer cells by guiding the migration rather than directly stimulating the cancer cells. In fact, in vitro co-culture experiments have suggested that cells of stromal origin are leading invasive cells by degrading the ECM through a combination of protease and force-mediated remodelling. Then, CAFs trigger structural modification of the ECM in order to pave the way towards the invasive cells [35]. In any case, it could be the cooperative interaction of these stromal cells with the epithelia that may lead to the invasive phenotype.

Enhanced expression and activation of matrix metalloproteinases (MMPs) by CAFs can also contribute to the remodelling of the ECM and thereby promote cell invasion. During normal homeostasis, MMPs keep the ECM in a balanced and well-organized state [36]. Overexpression of MMPs, however, can cause severe remodelling of the ECM, facilitating invasion and metastasis. In their study, Li et al. co-cultured primary CAFs with adenoid carcinoma cells (ACC) using a microfluidic device, where CAFs invaded the Matrigel via MMP activity. This could suggest that, besides the secretion of soluble factors, CAFs can create an invasive track in the ECM allowing other cells to follow them [37].

Fibroblast activation protein (FAP), a type II membrane bound glycoprotein, can also contribute to matrix reorganization by acting as a serine protease to degrade type I collagen [38]. Lee et al. described that FAP acts through various proteins by modulating the protein levels, and also through increasing levels of fibronectin and collagen fiber organization. As such FAP promotes tumour invasion [39] (Figure 3). In a different study, Wang et al. reported that overexpression of FAP in a human hepatic stellate cell line caused cell migration via activation of ECM proteins, including MMP2 [40]. FAP expression levels have been found to correlate with poor disease prognosis in several types of cancer, including colon [41], pancreatic [42], and hepatocellular carcinoma [43]. Being the predominant component of cancer stroma in most types of cancer [38], FAP can therefore be considered a significant target for therapeutic intervention, which will be discussed in later sections. 


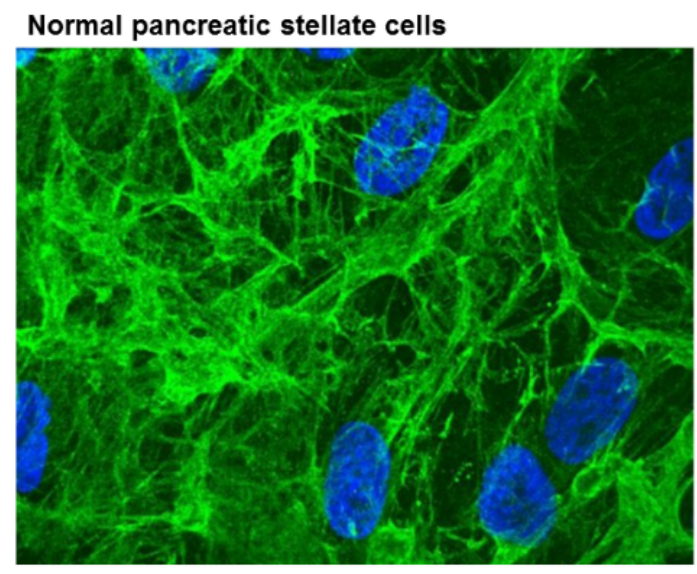

\section{Pancreatic adenocarcinoma fibroblasts}

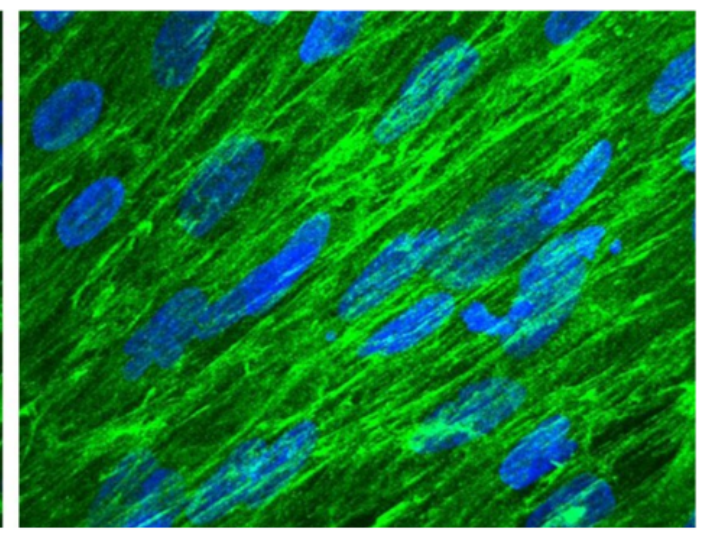

Figure 3. ECM fiber structures from normal pancreatic stellate cells and pancreatic adenocarcinoma associated fibroblasts stained for anti-fibronectin (green). ECMs organized in parallel patterns were observed in pancreatic adenocarcinoma fibroblasts that are similar to those formed by FAP-positive matrices. In contrast, ECM structures of normal pancreatic stellate cells resemble more FAP-negative matrices. Nuclei were stained with DAPI (blue). Reproduced with permission from [39].

\subsection{Angiogenesis}

Tumour growth and metastasis highly depend on angiogenesis for the tumour to develop, as the formation of new blood vessels is essential for the supply of oxygen and nutrients [44]. CAFs are capable to produce angiogenic factors, such as VEGF, and their production is induced by several components, the most important being hypoxia. In response to such conditions, CAFs upregulate the expression of VEGF protein in a manner that depends on oxygen deprivation [45]. CAFs can also affect angiogenesis through other angiogenic factors [46]. For example, the platelet derived growth factor/Platelet derived growth factor receptor (PDGF/PDGFR) signalling pathway has been described in angiogenesis through its involvement in CAF-mediated activation of VEGF. More specifically, PDGF directly attracts CAFs that secrete VEGF and thereby indirectly promotes angiogenesis [47].

Secretion of interleukin-6 (IL-6) by CAFs has also been reported to play a role in angiogenesis. IL-6 has the features of an angiogenic cytokine and was originally identified as a regulator of immune and inflammatory responses [48]. It is involved in various processes such as cell proliferation, migration, and angiogenesis. Dysregulated IL-6 production is associated with poor prognosis in many cancer types [49]. It was found that gastric cancer-derived isolated CAFs produced high amounts of IL-6 that enhance migration and EndMT of gastric cancer cells, a phenotype that was abrogated by inhibition of IL-6 [50]. These findings suggested that IL- 6 can be directly inhibited to enhance responsiveness to therapy.

\subsection{CAFs and Immune Response}

It is becoming more and more evident that there is a cross-talk not only between tumour cells and immune cells, but also between CAFs and immune cells. This is because CAFs have been implied to affect both innate and adaptive immune responses [51].

Cells of the innate immune response (macrophages, neutrophils, dendritic cells (DC), natural killer cells (NK), mast cells, and cytotoxic T-lymphocytes) act as early responders to cancer-mediated inflammation, and also as precursors for the adaptive immunity [52]. The interaction between CAFs and M2 macrophages, carrying distinct signatures (e.g., high expression levels of FAP, $\alpha$-SMA, and FSP1 for CAFs and expression of CD163 and Dendritic-Cell specific intercellular adhesion molecule-3-Grabbing Non-Integrin (DCSIGN) for macrophages), was reported in advanced colon cancer patients, and their co-presence was correlated with a differential disease progression and survival [53]. In particular high mRNA levels of CAF markers were correlated with poor disease-free survival and overall survival and when combined with M2 macrophage markers, these correlations became 
even more pronounced. In PDAC it was hypothesized that the communication between tumour cells and CAFs may be the initiator of cancer-associated inflammation [54]. This hypothesis was supported by the finding that the in vitro secretome of CAFs included immune cell chemokines (i.e., SDF-1) and anti-inflammatory proteins (i.e., CXCL6/GCP-2) that regulate the inflammatory response [54]. Pancreatic CAF precursors, known also as stellate cells, have been reported to interact with mast cells (e.g., a cell type that covers vessels and takes part in allergic responses) and tumour cells in models of PDAC. Together, tumour cells and stellate cells could activate mast cells in vitro, as was indicated by the mast cell release of TNF- $\alpha$, thereby promoting tumour cell migration. Blocking this interaction led to tumour suppression [55].

With regards to cells of the adaptive immune system, the relationship between CAFs and the adaptive immune response is yet to be fully elucidated. This is in part due to the lack of sufficient and relevant multi-cellular in vitro assays as well as the majority of in vivo studies being performed in immune-suppressed animal models, both impeding the effects that CAFs can have on T cells. During early tumour initiation, naïve T cells are activated and migrate to the TME in order to eliminate cancer cells [56]. Findings from in vivo models suggest that when targeting specific CAF-related molecules, attenuation of tumour growth and metastasis will appear followed by a change of $\mathrm{T}$ cell response. For example, ablation of FAP-positive CAFs in vivo, in a breast cancer model, led to a switch from Th2- to Th1-type immunity (T cell mediated immune response is classified in Th1- or Th2-type immunity, based on the cytokine expression profile), followed by expression of cytotoxic cytokines IL-2 and IL-7 and increased CD8 ${ }^{+}$T cell tumour infiltration, all critical for tumour immunotherapy [57].

In 2013, Pena et al. reported that PDGF-activated fibroblasts could increase migration and invasion of colorectal cancer cells, a process driven by the glycoprotein stanniocalcin-1 (STC1) [58]. STC1 is known to exert anti-inflammatory responses that affect both the innate and adaptive immune system, either by affecting macrophage function through induction of UCP2 (e.g., reduces mitochondrial membrane potential necessary for proper immune response) [59], or via inhibiting the migration of both human macrophages and T-cells towards human umbilical vein endothelial cells (HUVEC) [60].

In short, these studies and others [61-63] suggest that during tumorigenesis, CAFs acquire the ability to recruit immune cells and later on modulate them to an immunosuppressive phenotype that is compatible with disease progression.

In light of the functional and morphological heterogeneity, one question that frequently appears is how does the transition of a normal fibroblast to CAF really occur? Studies suggest both genetic alterations $[63,64]$ and epigenetic changes that may account responsible for this tumour-promoting phenotype, with the latest being the most prevalent [65-69].

\subsection{The Role of miRNAs in CAFs}

MicroRNAs (miRNA), which negatively regulate gene expression at a post-transcriptional level, have been reported to be involved in the conversion of fibroblasts to CAFs [69]. CAFs isolated from patients and analysed for miRNA expression presented 11 altered miRNAs when compared to normal fibroblasts [70]. Of those, three miRNAs (miR-221-5p, miR-31-3p, miR-221-3p) were found to be up-regulated, and eight (miR-205, miR-200b, miR-200c, miR-141, miR-101, miR-343-3p, let-7g, miR-26b) were down-regulated in CAFs. All 11 miRNAs affect important signalling pathways, such as those activated by IL-6, TGF$\beta$, and hepatocyte growth factor, playing essential roles in cell proliferation, differentiation, cell migration, and interaction with TME components. It is noteworthy that CAFs could be transformed back to normal fibroblasts by mimicking this downregulation via gene transfer of miRNAs and miRNA inhibitors. On the other hand, normal fibroblasts containing reprogrammed miRNA showed upregulated expression of genes similar to CAFs. These genes were highly enriched in chemokines, known to be important in CAF function. This illustrates that miRNAs contribute to the cross-talk between CAFs and tumour cells. The 
aforementioned investigations provide strong evidence that epigenetic markers can be essential therapeutic targets for CAFs, and consequently for the TME.

\section{Targeting CAFs as an Approach to Anti-Cancer Therapy}

As mentioned earlier, a number of studies have suggested that CAFs and their actions are linked to disease outcome and therefore appear as a very attractive target for the development of anticancer therapies. In the past years, many have tried to target CAFs either directly by promoting conversion to a more normal fibroblast phenotype or indirectly by influencing their communication with nearby cells. Our increasing knowledge of CAF biology has led to more pre-clinical studies developing novel FAP-targeting anti-cancer strategies that could potentially show great promise in the clinic.

Several approaches have been applied on the targeting of CAF-related surface markers, such as FAP and $\alpha$-SMA [71], since they are highly expressed in a number of tumour tissues, including pancreatic, lung, and breast cancer [72]. Some of these novel approaches include the use of monoclonal antibodies (mAb), small molecules [73], or chimeric antigen receptor (CAR) T-cells [74]; immunotherapy [75]; targeting of metabolism; conversion strategies.

\subsection{Use of Antibodies, Small Molecules, or CAR-T Cells}

The expression of FAP is unique for CAFs; FAP expression in other cells and tissues have been reported to be near undetectable [76]. This has led to the believe that chemical inhibition of FAP could have a therapeutic effect. In line with this, multiple FAP-targeting antibodies and smaller molecules have been developed and evaluated.

Ostermann et al. developed a promising mAb against FAP (FAP5-DM1), which showed long-lasting inhibition of tumour growth and good tolerability in preclinical mouse models of pancreatic, lung, and head-and-neck cancer [73]. Unfortunately, no tumour regression was observed during clinical trials in the majority of patients and the maximum tolerated dose was not reached with this $\mathrm{mAb}$ [77].

In 2013, Roberts et al. reported that depletion of FAP-positive cells from three sites (e.g., skeletal muscle, adipose tissue and pancreas) caused loss of muscle mass and reduction of erythropoiesis, and B-lymphopoiesis inducing cachexia and anaemia in mice [78]. This study strongly advocates that strategies targeting CAFs must consider the potential side effects that may appear under such a regime. Meanwhile, Feig and coworkers showed that depletion of FAP-positive CAFs, in PDAC-bearing mice, enabled the immune control of tumour growth and the antitumour activities of $\alpha$-CTLA-4 and PDL1 antibodies [79].

Peptide-like small molecule inhibitors, such as Val-boro-Pro (also known as Talabostat or PT-100), were initially developed to target dipeptidyl peptidase IV (DPPIV) but also showed effect on FAP [80]. This inhibitor was tested in several clinical trials for the treatment of different types of cancer [81], yet never got approval for clinical use. It did manage however, to form the starting point for the development of FAP inhibitors with improved activity, better stability and higher selectivity [82-84]. Currently, the best available FAP inhibitor described in literature is UAMC-1110. UAMC-1110 has low nanomolar activity combined with more than 500-fold specificity for FAP over off-target peptidases such as DPPIV and PREP [85]. Currently, the effectiveness of UAMC-1110 and its analogues have been evaluated pre-clinically and to the best of our knowledge no reports of clinical evaluation are available.

In another study, Lo et al. demonstrated that depletion by adoptive transfer of FAPtargeted CAR T-cells caused immune independent effects on tumour growth through reduction of ECM components, either directly by disrupting stromal-cell and matrix-dependent signalling in tumour cells, or by inhibition of angiogenesis [74]. It was also reported that depletion of FAP-expressing cells in Lewis lung carcinoma tumour models triggered acute hypoxic death of both tumour cells and stroma cells, that was regulated by interferon- $\gamma$ (IFN- $\gamma$ ) and tumour-necrosis factor- $\alpha$ (TNF- $\alpha$ ). The authors suggested that such a strategy, in combination with other immune-therapeutics, may be more beneficial [86]. 
Furthermore, therapeutics currently entering clinical trials might be more efficient when combined with CAF-targeting approaches. Hirata et al. reported that melanoma cells carrying BRAF mutations are more tolerant to the BRAF inhibitor, PLX4720, in areas where dense stroma is present. The authors suggested that PLX4720 has an effect on tumour stroma through ECM remodelling and supplies signals that make tumour cells more tolerant to therapeutic interventions [87].

\subsection{Blocking CAF Function with IL-6}

Sun et al. showed for the first time that IL-6, produced by CAFs, supported degradation of oestrogen receptor- $\alpha(E R-\alpha)$ via the ubiquitin-proteasome pathway. Upon administration of a proteasome inhibitor, sensitivity to chemotherapy was restored in breast cancer cells. The decreased expression of ER- $\alpha$ was suggested to be due to the induction of EMT by IL-6, and these effects disappeared by targeting CAFs with a IL-6 neutralizing antibody [88]. Since IL-6 is the main mediator of such effects, it could be targeted only in a portion of CAFs and therefore more precise markers are needed to efficiently discriminate IL-6-producing CAFs from the rest of the population.

\subsection{Hijacking the Metabolic Needs}

Tumour cells largely depend on glucose and glutamine for their metabolic needs and may hijack CAF metabolism in order to meet those requirements. This specific cross-talk between tumour cells and CAFs provides applications for anticancer therapy [89]. In prostate cancer, elevated glutamine levels were detected in CAFs, which correlated with activation of signalling pathways in tumour cells, most importantly RAS. As a result, the CAFderived glutamine supports the mitochondrial metabolism and induces neuroendocrine differentiation and consequently resistance to androgen deprivation therapy (ADT) [90].

In PDAC, the pancreatic stellate cells constitute a major cell type of the tumour stroma. Upon activation, due to production of cytokines or oxidative stress, they abnormally proliferate and produce a large number of ECM components until they establish a myofibroblasts-like phenotype [91]. It is this phenotype that is responsible for the fibrotic environment observed in chronic pancreatitis and PDAC. In a study by Jacobetz et al., enzymatic breakdown of hyaluronic acid, a prominent component of the stroma environment, was shown to cause remodelling of microvasculature, leading to a more enhanced therapeutic response [92]. This highlighted a way of overcoming chemoresistance through impairment of the microenvironment.

\subsection{Conversion of CAFs to a Quiescent Phenotype}

Another approach that may potentially target CAFs is hidden in the regulatory pathways that cause the transformation of normal fibroblasts into CAFs [21]. In their extensive review paper, Melissary et al. provide a detailed overview of the currently known methods that fibroblasts use for their conversion into CAFs including synthetic activation, epigenetic and metabolic reprogramming [93]. Of those, the one most interesting is the Vitamin D receptor (VDR). VDR is expressed in the stroma environment of gastrointestinal tumours, acts as a modulator of CAFs and when targeted with the ligand calcipotriol, could reprogram CAFs to a more quiescent state, thereby reducing inflammation and pancreatitis [94]. However, the various functions of VDR still remain to be elucidated. In their recent study, Gorchs, et al. reported that even though pancreatic CAFs responded to therapeutic stimulation of VDR, by promoting a less tumour-supportive CAF phenotype, at the same time the $\mathrm{T}$ cell mediated response against tumour cells was less efficient [95]. This only raises questions about the suitability of such approach and maybe a combination with immunotherapy strategies can prove more beneficial.

The strategies described above (Figure 4) highlight the impact of targeting CAFs during treatment of cancer and also provide additional knowledge into their biology. Several approaches have been described and few are entering clinical testing and a number of them have been utilized to target CAFs with novel radiolabelled probes. The latter will 
be discussed in the following section. However, questions are still present that are related to the heterogeneity of this population and whether the same outcome will be observed in a clinical scenario. Careful analysis of the stromal responses will potentially aid our understanding of the source of CAF-mediated drug resistance, as well as spark a rational design for future patient studies targeting CAFs [10].

A

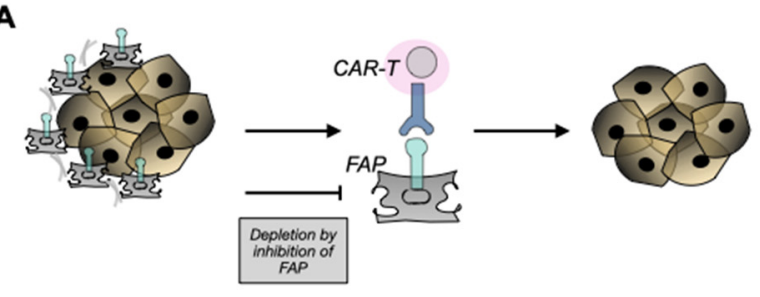

C

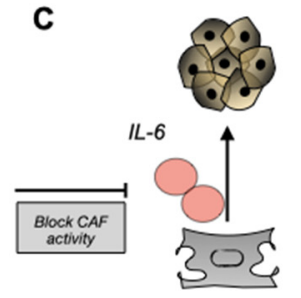

D

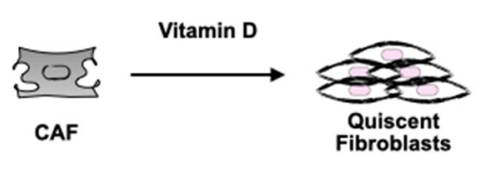

B

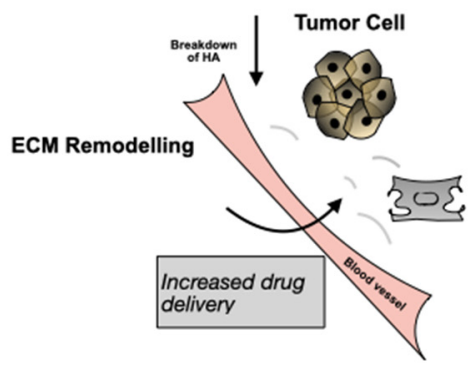

E

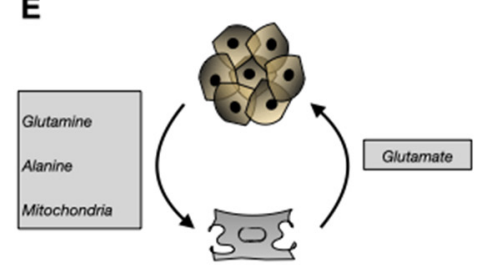

Figure 4. Overview of potential CAF interventions. (A) Use of anti-FAP mAbs or T-cells gene-engineered to express a FAP recognizing $\mathrm{mAb}$ (e.g., $\mathrm{CAR}-\mathrm{T}$ cells) target $\mathrm{FAP}^{+} \mathrm{CAFs}$ and result in their immune cell-mediated destruction and removal. (B) Enzymatic breakdown of HA may lead to remodelling of ECM and better tumour accessibility for drugs and/or immune cells. (C) Block CAF activity through IL-6. (D) Transform CAFs into a more quiescent state via Vitamin D. (E) Tackle the metabolic need of tumour cells and their dependence on CAF metabolism. FAP: fibroblast activated protein, CAR: chimeric antigen receptor, HA: hyaluronic acid, IL-6 interleukin-6.

\section{Targeting CAFs for Imaging and Therapy}

As described above, the tumour stroma represents an attractive target for the delivery of diagnostic and therapeutic compounds. As mentioned earlier, CAFs feature high expression of FAP that is not detectable in adult normal tissue but is associated with a poor prognosis in cancer patients [41,42]. Several approaches have been applied to target CAFs with novel radiolabelled probes based on antibodies, peptides and small molecule inhibitors in different cancer types [72,96].

Fischer et al. [97] selected novel human Fab fragments from an antibody phage library that bound both human and murine FAP, two candidates were engineered into fully human IgG1 antibodies with affinities in the low nanomolar range. Radioimmunotherapy with ${ }^{177} \mathrm{Lu}$-labeled anti-FAP antibodies in melanoma-bearing mice delayed growth of established tumours and extended mouse survival, showing the potential for diagnostic and therapeutic use. No clinical studies have been performed yet with these tracers.

The development of the selective and potent FAP inhibitor UAMC-1110 has led to synthetization of other promising radiolabelled FAP inhibitors tested in different tumour entities (FAPIs) [98-110]. In particularly the quinoline group of UAMC-1110 allows for chemical modification: on the 5 and 6 position different chelators have been attached via various linkers. Lindner et al. [105] were the first to synthesize radiolabelled FAP inhibitors (FAPIs). Giesel et al. [98] described the tissue biodistribution and preliminary dosimetry of $\left[{ }^{68} \mathrm{Ga}\right] \mathrm{Ga}-F A P I-2$ and $\left[{ }^{68} \mathrm{Ga}\right] \mathrm{Ga}-F A P I-4$ in two patients, whereas further PET/CT scans were acquired of 25 patients. Similar to literature values for $\left[{ }^{18} \mathrm{~F}\right] \mathrm{FDG}$ (Average $\mathrm{SUV}_{\max }$

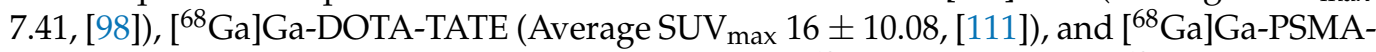
11 (Average SUV $\max 11.3 \pm 7.5$, [112]) $200 \mathrm{MBq}$ of $\left[{ }^{68} \mathrm{Ga}\right] \mathrm{Ga}-\mathrm{FAPI}-2$ or $\left[{ }^{68} \mathrm{Ga}\right] \mathrm{Ga}-\mathrm{FAPI}-4$ corresponded to an equivalent dose of approximately 3-4 mSv. Using $\left[{ }^{68} \mathrm{Ga}\right] \mathrm{Ga}-\mathrm{FAPI}-2$, 
the tumour uptake from 1 to $3 \mathrm{~h}$ after injection decreased by $75 \%$, whereas for $\left[{ }^{68} \mathrm{Ga}\right] \mathrm{Ga}$ FAPI-4 this was only $25 \%$. In comparison to $\left.{ }^{18} \mathrm{~F}\right] \mathrm{FDG}$ at $1 \mathrm{~h}$ after injection, tumour uptake was almost equal. Continuing with $\left[{ }^{68} \mathrm{Ga}\right]-F A P I-4$ PET/CT, Kratochwil et al. [103] quantified tumour uptake in eighty patients. The highest average SUVmax was found in sarcoma, oesophageal, breast, cholangiocarcinoma, and lung cancer, the lowest in pheochromocytoma, renal cell, differentiated thyroid, adenoid cystic, and gastric cancer, whereas the average SUVmax of hepatocellular, colorectal, head-neck, ovarian, pancreatic, and prostate cancer was intermediate. Because of low background in muscle and blood pool, tumour-to-background (TBR) contrast ratios were more than 3 -fold in the intermediate and more than 6-fold in the high-intensity uptake group. FAP-specific PET imaging was also applied preclinically and clinically in gliomas [109]. IDH-wildtype glioblastomas and grade III/IV, but not grade II, IDH-mutant gliomas showed elevated tracer uptake. Immunohistochemistry showed FAP-positive cells in glioblastomas and an anaplastic IDH-mutant astrocytoma.

Next, several novel FAPI variants were described (Table 1). Tumour-to-normal-organ ratios were improved for most of the compounds, resulting in images with higher contrast, especially for FAPI-21 and -46 [106]. A separate study performed with $\left[{ }^{68} \mathrm{Ga}\right] \mathrm{Ga}-\mathrm{FAPI}-46$ showed a favourable dosimetry profile with an estimated whole-body dose of $5.3 \mathrm{mSv}$ for an administration of $200 \mathrm{MBq}$. The biodistribution study showed high TBRs increasing over time, making this an interesting tracer for future theranostic applications [108].

Loktev et al. [107] developed promising iodinated (FAPI-1) and DOTA-coupled (FAPI2) radiotracers also based on FAPI. FAPI-1 showed time-dependent efflux and robust deiodination, whereas FAPI-2 showed enhanced binding and uptake to human FAP as compared with FAPI-01. [ $\left.{ }^{99 \mathrm{~m}} \mathrm{Tc}\right] \mathrm{Tc}-\mathrm{FAPIs}$ were developed as well and showed specific binding to recombinant FAP-expressing cells with high affinity [104]. The lead candidate $\left[{ }^{99 \mathrm{~m}} \mathrm{Tc}\right] \mathrm{Tc}-\mathrm{FAPI}-34$ was applied for diagnostic scintigraphy and SPECT of patients with metastasized ovarian and pancreatic cancer for follow-up to therapy with [ $\left.{ }^{90} \mathrm{Y}\right] \mathrm{Y}$-FAPI-46. $\left[{ }^{99 \mathrm{~m}} \mathrm{Tc}\right] \mathrm{Tc}-\mathrm{FAPI}-34$ accumulated in the tumour lesions also shown in PET/CT imaging using $\left[{ }^{68} \mathrm{Ga}\right] \mathrm{Ga}-\mathrm{FAPI}-46$, making this a powerful tracer for diagnostic scintigraphy, especially in cases where PET imaging is not available. Additionally, the chelator used in this compound allows labelling with the therapeutic radionuclide ${ }^{188} \mathrm{Re}$. Watabe et al. applied radionuclides with relatively long half-lives, ${ }^{64} \mathrm{Cu}$ and ${ }^{225} \mathrm{Ac}$ to label FAPIs for studies in mice with human pancreatic cancer xenografts. Accumulation levels in the tumour and most normal organs were significantly higher for $\left[{ }^{64} \mathrm{Cu}\right] \mathrm{Cu}$-FAPI-4 than for $\left[{ }^{68} \mathrm{Ga}\right] \mathrm{Ga}$-FAPI4. $\left[{ }^{225} \mathrm{Ac}\right] \mathrm{Ac}-\mathrm{FAPI}-4$ injection showed significant tumour growth suppression in PANC-1 xenograft mice indicating that $\left[{ }^{64} \mathrm{Cu}\right] \mathrm{Cu}-\mathrm{FAPI}-4$ and $\left[{ }^{225} \mathrm{Ac}\right] \mathrm{Ac}-\mathrm{FAPI}-4$ could be used in theranostics for the treatment of FAP-expressing pancreatic cancer [101].

Toms et al. [102] synthesized an ${ }^{18} \mathrm{~F}$-labelled FAPI ([$\left.\left.{ }^{18} \mathrm{~F}\right] \mathrm{FGlc}-\mathrm{FAPI}\right)$ and concluded from a preclinical study it is an interesting candidate for translation to the clinic, taking advantage of the longer half-life and physical imaging properties of ${ }^{18} \mathrm{~F}$. Giesel et al. [113] describe the NOTA-chelator ligand FAPI-74 that can be labeled with both $\mathrm{Al}\left[{ }^{18} \mathrm{~F}\right] \mathrm{F}$ and ${ }^{68} \mathrm{Ga}$. In ten patients with lung cancer PET-scans were acquired after administration of $\left[{ }^{18} \mathrm{~F}\right] \mathrm{F}-\mathrm{FAPI}-74$, with the highest contrast achieved $1 \mathrm{~h}$ p.i. in primary tumours, lymph node and distant metastases with SUVmax $>10$, respectively. The radiation burden of a diagnostic $\left[{ }^{18}\right.$ F]F-FAPI-74 PET-scan was lower than that of PET-scans with $\left[{ }^{18}\right.$ F]F-FDG and other $\left[{ }^{18} \mathrm{~F}\right] \mathrm{F}$-tracers, whereas $\left[{ }^{68} \mathrm{Ga}\right] \mathrm{Ga}$-FAPI-74 was comparable to other ${ }^{68} \mathrm{Ga}$-ligands. The high contrast and low radiation burden of FAPI-74 PET/CT favours multiple clinical applications. So, tumour-to-background contrast ratios of different FAPIs were equal to or even better than those of $\left[{ }^{18} \mathrm{~F}\right] \mathrm{FDG}[98,114]$. In contrast to $\left[{ }^{18} \mathrm{~F}\right] \mathrm{FDG}$, no diet or fasting in preparation for the examination is necessary, and image acquisition can potentially start a few minutes after tracer application. Despite their advantages, utilization of FAPIs in the clinic may face some limitations as there is still not enough information on its specificity, suggesting a decreased performance in patients who might have other diseases that are characterized by high levels of fibrosis. 
Table 1. FAP-targeting tracers used for theranostic applications.

\begin{tabular}{|c|c|c|c|c|}
\hline Tracer & Chemical Structure & Radionuclides & Application & References \\
\hline FAPI-2 & & $\begin{array}{l}\text { PET: }{ }^{68} \mathrm{Ga} \\
\text { Therapy: }{ }^{177} \mathrm{Lu}\end{array}$ & Various Cancers & [98] \\
\hline FAPI-4 & & $\begin{array}{c}\text { PET: }{ }^{68} \mathrm{Ga}^{64} \mathrm{Cu} \\
\text { Therapy: }{ }^{60} \mathrm{Y}^{177}{ }^{17 u},{ }^{225} \mathrm{Ac}\end{array}$ & Breast Cancer & [105] \\
\hline FAPI-21 & & $\begin{array}{l}\text { PET: }{ }^{68} \mathrm{Ga} \\
\text { Therapy: }{ }^{177} \mathrm{Lu}\end{array}$ & Ovarian and Colorectal Cancer & [106] \\
\hline FAPI- 46 & & $\begin{array}{l}\text { PET: }{ }^{68} \mathrm{Ga} \\
\text { Therapy: }{ }^{90} \mathrm{Y}^{177} \mathrm{Lu}\end{array}$ & Colorectal, Mammary, Oropharyngeal Cancer & [106] \\
\hline FAPI-34 & & $\begin{array}{l}\text { SPECT: }:{ }^{99 \mathrm{~m}} \mathrm{Tc} \\
\text { Therapy: }{ }^{188} \mathrm{Re}\end{array}$ & $\begin{array}{c}\text { Pancreatic, } \\
\text { Ovarian Cancer }\end{array}$ & [104] \\
\hline FAPI-74 & & PET: ${ }^{18} \mathrm{~F}^{68} \mathrm{Ga}$ & Lung Cancer & [113] \\
\hline
\end{tabular}


The efficacy of clinical radioligand therapy via crossfire effects is not yet known. $\left[{ }^{90} \mathrm{Y}\right] \mathrm{Y}-\mathrm{FAPI}-4$ was chosen for a proof of principle approach in a final stage breast cancer patient with bone metastases [105]. This was associated with a significant reduction of opioids given as pain medication. Furthermore, no side effects were observed, especially no therapy-related hematotoxicity.

\section{Future Opportunities for FAP-Mediated Imaging and Treatment}

The results of the first FAPI tracers are very encouraging for theranostic applications for a wide variety of tumours. Here, we highlight several opportunities for future FAP tracers.

As most clinically valuable tracers belong to one family of small molecule tracers, based on FAP inhibitor UAMC-1110, it is currently the only available FAP inhibitor with low nanomolar activity and high selectivity. This calls for the development of novel small molecule FAP inhibitors, of which the scaffolds can be used for the design of new FAP theranostics with new and potentially improved properties. Another strategy, adopted by Clovis Oncology, is based on a peptidomimetic (FAP-2286) to target FAP [115] and the much anticipated results will provide more clues on this method. The properties of FAP (its location on the outside of the CAF membrane and its unique expression) makes it an interesting target for peptide receptor radionuclide therapy (PRRT). The best example of PRRT is that of targeting the Somatostatin receptor in Neuroendocrine tumour patients [116]. This therapeutic strategy is even EMA and FDA approved. To the best of our knowledge, no FAP-targeted peptide-based molecule that can be applied for PRRT is reported in literature. However, development of such molecules, through for example phage-display screening platforms or chemical inactivation of FAP peptide substrates, will open new opportunities for FAP theranostics. A number of antibodies against FAP have been also developed and despite their superiority, in terms of affinity and specificity, such molecules can be challenging in regards to toxicity towards healthy tissues. Third, an opportunity for developing FAP theranostics are stimuli-responsive tracers, in which the enzymatic activity of FAP itself and the environment created by CAFs and tumour cells is employed. For example, site-specific enzymatic cleavage of FAP can result in the formation of nanoparticles [117] or release of functionality [118]. Furthermore, due to metabolic changes in CAFs and cancer cells [28], the TME is acidified harbouring increased levels of $\mathrm{H}_{2} \mathrm{O}_{2}$ and glutathione. These tumour specific properties are currently evaluated in pro-drug strategies [119-121] and could be of value in developing theranostic tracers.

\section{Conclusions}

Despite the increasing progress in cancer research and the development of novel therapeutics, conventional therapeutics are not adequate enough. The majority of efforts so far were only focused on targeting the cancer cells and even though highly abundant, CAFs have long been ignored in these efforts. The emerging role of CAFs is slowly appearing to be of great importance and their functions in tumour progression and metastasis have become an attractive target for imaging and therapy. However, a number of challenges need to be addressed in order to reach translation from bench to bedside. Looking at their structural and functional complexity, diagnostic markers that can specifically recognize CAFs are still limited. This complexity is also outlined by the various CAF cell origins. In the TME, CAFs co-exist with tumour cells providing them the paracrine niche and nutrients that are needed for tumours to grow. Breaking this contact and pinpointing the role of each of the microenvironment compartments, may appear pivotal for discoveries of novel therapeutic interventions. Fortunately, technological advances over the past years are opening new opportunities in understanding the complex biology of CAFs in cancer and will pave the way for new targets that can be used in future developments, one of those targets being FAP. The high and rather selective tumour uptake of very promising FAP-targeting tracers as described opens up applications for non-invasive tumour characterization, staging 
examinations, and radioligand therapy in many different cancers with a high content of activated fibroblasts.

Author Contributions: S.K., M.W.H.H., and M.d.J. performed the literature search and wrote the manuscript. S.U.D., R.D., S.M., and Y.S. were involved in determining the outline of the manuscript as well as in reading and correcting the manuscript. All authors have read and agreed to the published version of the manuscript.

Funding: This study was funded by KWF Kankerbestrijding and the convergence health and technology grant between Erasmus MC and TU Delft.

Conflicts of Interest: The authors declare no conflict of interest.

\section{References}

1. Cancer [Internet]. Available online: https://www.who.int/news-room/fact-sheets/detail/cancer (accessed on 19 November 2020).

2. Valkenburg, K.C.; de Groot, A.E.; Pienta, K.J. Targeting the tumour stroma to improve cancer therapy. Nat. Rev. Clin. Oncol. 2018, 15, 366-381. [CrossRef]

3. Yuan, Y.; Jiang, Y.C.; Sun, C.K.; Chen, Q.M. Role of the tumor microenvironment in tumor progression and the clinical applications (Review). Oncol. Rep. 2016, 35, 2499-2515. [CrossRef]

4. Balkwill, F.R.; Capasso, M.; Hagemann, T. The tumor microenvironment at a glance. J. Cell Sci. 2012, 125, 5591-5596. [CrossRef]

5. Liu, L.; Liu, L.; Yao, H.H.; Zhu, Z.Q.; Ning, Z.L.; Huang, Q. Stromal myofibroblasts are associated with poor prognosis in solid cancers: A meta-analysis of published studies. PLoS ONE 2016, 11, e0159947. [CrossRef] [PubMed]

6. Trabelsi, M.; Farah, F.; Zouari, B.; Jaafoura, M.H.; Kharrat, M. An immunoscore system based on cd3+ and cd8+ infiltrating lymphocytes densities to predict the outcome of patients with colorectal adenocarcinoma. Onco. Targets. Ther. 2019, 12, 8663-8673. [CrossRef] [PubMed]

7. Liu, T.; Zhou, L.; Li, D.; Andl, T.; Zhang, Y. Cancer-associated fibroblasts build and secure the tumor microenvironment. Front. Cell Dev. Biol. 2019, 7, 1-14. [CrossRef] [PubMed]

8. Öhlund, D.; Handly-Santana, A.; Biffi, G.; Elyada, E.; Almeida, A.S.; Ponz-Sarvise, M.; Corbo, V.; Oni, T.E.; Hearn, S.A.; Lee, E.J.; et al. Distinct populations of inflammatory fibroblasts and myofibroblasts in pancreatic cancer. J. Exp. Med. 2017, 214, 579-596. [CrossRef] [PubMed]

9. Kalluri, R. The biology and function of fibroblasts in cancer. Nat. Rev. Cancer 2016, 6, 582-598. [CrossRef] [PubMed]

10. Flier, J.S.; Underhill, L.H.; Dvorak, H.F. Tumors: Wounds That Do Not Heal. N. Engl. J. Med. 1986, 315, 1650-1659. [CrossRef]

11. Liu, T.; Han, C.; Wang, S.; Fang, P.; Ma, Z.; Xu, L.; Yin, R. Cancer-associated fibroblasts: An emerging target of anti-cancer immunotherapy. J. Hematol. Oncol. 2019, 12, 1-15. [CrossRef]

12. Sahai, E.; Astsaturov, I.; Cukierman, E.; DeNardo, D.G.; Egeblad, M.; Evans, R.M.; Fearon, D.; Greten, F.R.; Hingorani, S.R.; Hunter, T.; et al. A framework for advancing our understanding of cancer-associated fibroblasts. Nat. Rev. Cancer 2020, 20, 174-186. [CrossRef]

13. Kojima, Y.; Acar, A.; Eaton, E.N.; Mellody, K.T.; Scheel, C.; Ben-Porath, I.; Onder, T.T.; Wang, Z.C.; Richardson, A.L.; Weinberg, R.A.; et al. Autocrine TGF- $\beta$ and stromal cell-derived factor-1 (SDF-1) signaling drives the evolution of tumorpromoting mammary stromal myofibroblasts. Proc. Natl. Acad. Sci. USA 2010, 107, 20009-20014. [CrossRef]

14. Löhr, M.; Schmidt, C.; Ringel, J.; Kluth, M.; Müller, P.; Nizze, H.; Jesnowski, R. Transforming growth factor- $\beta 1$ induces desmoplasia in an experimental model of human pancreatic carcinoma. Cancer Res. 2001, 61, 550-555. [PubMed]

15. Bu, L.; Baba, H.; Yoshida, N.; Miyake, K.; Yasuda, T.; Uchihara, T.; Tan, P.; Ishimoto, T. Biological heterogeneity and versatility of cancer-associated fibroblasts in the tumor microenvironment. Oncogene 2019, 38, 4887-4901. [CrossRef]

16. Mishra, P.J.; Mishra, P.J.; Humeniuk, R.; Medina, D.J.; Alexe, G.; Mesirov, J.P.; Ganesan, S.; Glod, J.W.; Banerjee, D. Carcinomaassociated fibroblast-Like differentiation of human MSC. Cancer 2009, 68, 4331-4339. [CrossRef]

17. Weber, C.E.; Kothari, A.N.; Wai, P.Y.; Li, N.Y.; Driver, J.; Zapf, M.A.C.; Franzen, C.A.; Gupta, G.N.; Osipo, C.; Zlobin, A.; et al. Osteopontin mediates an MZF1-TGF- $\beta 1$-dependent transformation of mesenchymal stem cells into cancer-associated fibroblasts in breast cancer. Oncogene 2015, 34, 4821-4833. [CrossRef]

18. Zeisberg, E.M.; Tarnavski, O.; Zeisberg, M.; Dorfman, A.L.; McMullen, J.R.; Gustafsson, E.; Chandraker, A.; Yuan, X.; Pu, W.T.; Roberts, A.B.; et al. Endothelial-to-mesenchymal transition contributes to cardiac fibrosis. Nat. Med. 2007, 13, 952-961. [CrossRef]

19. Tomiyama, K.; Murase, N.; Stolz, D.B.; Toyokawa, H.; O’Donnell, D.R.; Smith, D.M.; Dudas, J.R.; Rubin, J.P.; Marra, K.G. Characterization of transplanted GFP+ bone marrow cells into adipose tissue. Stem Cells 2008, 26, 330-338. [CrossRef]

20. Barth, P.J.; Ebrahimsade, S.; Ramaswamy, A.; Moll, R. CD34+ fibrocytes in invasive ductal carcinoma, ductal carcinoma in situ, and benign breast lesions. Virchows Arch. 2002, 440, 298-303. [CrossRef]

21. LeBleu, V.S.; Kalluri, R. A peek into cancer-associated fibroblasts: Origins, functions and translational impact. DMM Dis. Model. Mech. 2018, 11, 1-9. [CrossRef]

22. Olumi, A.F.; Grossfeld, G.D.; Hayward, S.W.; Carroll, P.R.; Tlsty, T.D.; Cunha, G.R. Carcinoma-associated fibroblasts direct tumor progression of initiated human prostatic epithelium. Cancer Res. 1999, 59, 5002-5011. 
23. Hanahan, D.; Weinberg, R.a. Hallmarks of cancer: The next generation. Cell 2011, 144, 646-674. [CrossRef]

24. Bhowmick, N.A.; Neilson, E.G.; Moses, H.L. 6 Moses. 2004, p. 432. Available online: www.nature.com/nature (accessed on 25 February 2021).

25. Kuperwasser, C.; Chavarria, T.; Wu, M.; Magrane, G.; Gray, J.W.; Carey, L.; Richardson, A.; Weinberg, R.A. Reconstruction of functionally normal and malignant human breast tissues in mice. PNAS 2004, 101, 4966-4971. [CrossRef]

26. Grum-Schwensen, B.; Klingelhofer, J.; Berg, C.H.; El-Naaman, C.; Grigorian, M.; Lukanidin, E.; Ambartsumian, N. Suppression of tumor development and metastasis formation in mice lacking the S100A4(mts1) gene. Cancer Res. 2005, 65, 3772-3780. [CrossRef] [PubMed]

27. Li, G.; Satyamoorthy, K.; Meier, F.; Berking, C.; Bogenrieder, T.; Herlyn, M. Function and regulation of melanoma-stromal fibroblast interactions: When seeds meet soil. Oncogene 2003, 22, 3162-3171. [CrossRef]

28. Avagliano, A.; Granato, G.; Ruocco, M.R.; Romano, V.; Belviso, I.; Carfora, A.; Montagnani, S.; Arcucci, A. Metabolic Reprogramming of Cancer Associated Fibroblasts: The Slavery of Stromal Fibroblasts. Biomed Res. Int. 2018, 2018. [CrossRef] [PubMed]

29. Powell, D.W. Myofibroblasts: Paracrine cells important in health and disease. Trans. Am. Clin. Climatol. Assoc. 2000, 111, 271-293. [CrossRef] [PubMed]

30. Yang, N.; Xiao, W.; Song, X.; Wang, W.; Dong, X. Recent Advances in Tumor Microenvironment Hydrogen Peroxide-Responsive Materials for Cancer Photodynamic Therapy. Nano-Micro Lett. 2020, 12, 1-27. [CrossRef]

31. Rhim, A.D.; Oberstein, P.E.; Thomas, D.H.; Mirek, E.T.; Palermo, F.; Sastra, S.A.; Dekleva, E.N.; Saunders, T.; Becerra, C.P.; Tattersall, I.W.; et al. Stromal elements act to retrain rather than support pdac. Cancer Cell 2014, 25, 735-747. [CrossRef]

32. Brechbuhl, H.M.; Finlay-Schultz, J.; Yamamoto, T.M.; Gillen, A.E.; Cittelly, D.M.; Tan, A.C.; Sams, S.B.; Pillai, M.M.; Elias, A.D.; Robinson, W.A.; et al. Fibroblast subtypes regulate responsiveness of luminal breast cancer to estrogen. Clin. Cancer Res. 2017, 23, 1710-1721. [CrossRef] [PubMed]

33. Lukashev, M.E.; Werb, Z. ECM signalling: Orchestrating cell behaviour and misbehaviour. Trends Cell Biol. 1998, 8, 437-441. [CrossRef]

34. Fukumura, D.; Xavier, R.; Sugiura, T.; Chen, Y.; Park, E.C.; Lu, N.; Selig, M.; Nielsen, G.; Taksir, T.; Jain, R.K.; et al. Tumor induction of VEGF promoter activity in stromal cells. Cell 1998, 94, 715-725. [CrossRef]

35. Gaggioli, C.; Hooper, S.; Hidalgo-Carcedo, C.; Grosse, R.; Marshall, J.F.; Harrington, K.; Sahai, E. Fibroblast-led collective invasion of carcinoma cells with differing roles for RhoGTPases in leading and following cells. Nat. Cell Biol. 2007, 9, 1392-1400. [CrossRef]

36. Lu, P.; Takai, K.; Weaver, V.M.; Werb, Z. Extracellular Matrix degradation and remodeling in development and disease. Cold Spring Harb. Perspect. Biol. 2011, 3, 1-24. [CrossRef]

37. Li, J.; Jia, Z.; Kong, J.; Zhang, F.; Fang, S.; Li, X.; Li, W.; Yang, X.; Luo, Y.; Lin, B.; et al. Carcinoma-associated fibroblasts lead the invasion of salivary gland adenoid cystic carcinoma cells by creating an invasive track. PLoS ONE 2016, 11, 1-15. [CrossRef] [PubMed]

38. Liu, R.; Li, H.; Liu, L.; Yu, J.; Ren, X. Fibroblast activation protein: A potential therapeutic target in cancer. Cancer Biol. Ther. 2012, 13, 123-129. [CrossRef] [PubMed]

39. Lee, H.O.; Mullins, S.R.; Franco-Barraza, J.; Valianou, M.; Cukierman, E.; Cheng, J.D. FAP-overexpressing fibroblasts produce an extracellular matrix that enhances invasive velocity and directionality of pancreatic cancer cells. BMC Cancer 2011, 11, 245. [CrossRef]

40. Wang, X.M.; Yu, D.M.T.; McCaughan, G.W.; Gorrell, M.D. Fibroblast activation protein increases apoptosis, cell adhesion, and migration by the LX-2 human stellate cell line. Hepatology 2005, 42, 935-945. [CrossRef]

41. Henry, L.R.; Lee, H.O.; Lee, J.S.; Klein-Szanto, A.; Watts, P.; Ross, E.A.; Chen, W.T.; Cheng, J.D. Clinical implications of fibroblast activation protein in patients with colon cancer. Clin. Cancer Res. 2007, 13, 1736-1741. [CrossRef] [PubMed]

42. Cohen, S.J.; Alpaugh, R.K.; Palazzo, I.; Meropol, N.J.; Rogatko, A.; Xu, Z.; Hoffman, J.P.; Weiner, L.M.; Cheng, J.D. Fibroblast activation protein and its relationship to clinical outcome in pancreatic adenocarcinoma. Pancreas 2008, 37, 154-158. [CrossRef]

43. Ju, M.J.; Qiu, S.J.; Fan, J.; Xiao, Y.S.; Gao, Q.; Zhou, J.; Li, Y.W.; Tang, Z.Y. Peritumoral activated hepatic stellate cells predict poor clinical outcome in hepatocellular carcinoma after curative resection. Am. J. Clin. Pathol. 2009, 131, 498-510. [CrossRef] [PubMed]

44. Folkman, J. Role of angiogenesis in tumor growth and metastasis. Semin. Oncol. 2002, 29, 15-18. [CrossRef] [PubMed]

45. Hlatky, L.; Tsionou, C.; Hahnfeldt, P.; Coleman, C.N. Mammary Fibroblasts May Influence Breast Tumor Angiogenesis Via Hypoxia-Induced Vascular Endothelial Growth Factor Up-Regulation And Protein Expression. Cancer Res. 1994, 54, $6083-6086$.

46. Shiga, K.; Hara, M.; Nagasaki, T.; Sato, T.; Takahashi, H.; Takeyama, H. Cancer-associated fibroblasts: Their characteristics and their roles in tumor growth. Cancers 2015, 7, 2443-2458. [CrossRef]

47. Gomes, F.G.; Nedel, F.; Alves, A.M.; Nör, J.E.; Tarquinio, S.B.C. Tumor angiogenesis and lymphangiogenesis: Tumor/endothelial crosstalk and cellular/microenvironmental signaling mechanisms. Life Sci. 2014, 92, 101-107. [CrossRef]

48. Grivennikov, S.I.; Greten, F.R.; Karin, M.; Grivennikov, S.I.; Greten, F.R.; Karin, M. Immunity, inflammation, and cancer. Cell 2011, 140, 883-899. [CrossRef] [PubMed]

49. Nagasaki, T.; Hara, M.; Shiga, K.; Takeyama, H. Relationship between inflammation and cancer progression: Recent advances in interleukin-6 signaling and its blockage in cancer therapy. Recept. Clin. Investig. 2014, 1-7. [CrossRef]

50. Wu, X.; Tao, P.; Zhou, Q.; Li, J.; Yu, Z.; Wang, X.; Li, J.; Li, C.; Yan, M.; Zhu, Z.; et al. IL-6 secreted by cancer-associated fibroblasts promotes epithelial-mesenchymal transition and metastasis of gastric cancer via JAK2/STAT3 signaling pathway. Oncotarget 2017, 8, 20741-20750. [CrossRef] 
51. Harper, J.; Sainson, R.C.A. Regulation of the anti-tumour immune response by cancer-associated fibroblasts. Semin. Cancer Biol. 2014, 25, 69-77. [CrossRef]

52. An, Y.; Liu, F.; Chen, Y.; Yang, Q. Crosstalk between cancer-associated fibroblasts and immune cells in cancer. J. Cell. Mol. Med. 2020, 24, 13-24. [CrossRef]

53. Herrera, M.; Herrera, A.; Domínguez, G.; Silva, J.; García, V.; García, J.M.; Gómez, I.; Soldevilla, B.; Muñoz, C.; Provencio, M.; et al. Cancer-associated fibroblast and M2 macrophage markers together predict outcome in colorectal cancer patients. Cancer Sci. 2013, 104, 437-444. [CrossRef]

54. De Boeck, A.; Hendrix, A.; Maynard, D.; Van Bockstal, M.; Daniëls, A.; Pauwels, P.; Gespach, C.; Bracke, M.; De Wever, O. Differential secretome analysis of cancer-associated fibroblasts and bone marrow-derived precursors to identify microenvironmental regulators of colon cancer progression. Proteomics 2013, 13, 379-388. [CrossRef]

55. Ma, Y.; Hwang, R.F.; Logsdon, C.D.; Ullrich, S.E. Dynamic mast cell-stromal cell interactions promote growth of pancreatic cancer. Bone 2011, 23, 1-7. [CrossRef]

56. Gonzalez, H.; Hagerling, C.; Werb, Z. Roles of the immune system in cancer: From tumor initiation to metastatic progression. Genes Dev. 2018, 32, 1267-1284. [CrossRef] [PubMed]

57. Liao, D.; Luo, Y.; Markowitz, D.; Xiang, R.; Reisfeld, R.A. Cancer associated fibroblasts promote tumor growth and metastasis by modulating the tumor immune microenvironment in a 4T1 murine breast cancer model. PLoS ONE 2009, 4. [CrossRef]

58. Pena, C.; Cespedes, M.V.; Lindh, M.B.; Kiflemariam, S.; Mezheyeuski, A.; Edqvist, P.H.; Hagglof, C.; Birgisson, H.; Bojmar, L.; Jirstrom, K.; et al. STC1 expression by cancer-associated fibroblasts drives metastasis of colorectal cancer. Cancer Res. 2013, 73, 1287-1297. [CrossRef] [PubMed]

59. Wang, Y.; Huang, L.; Abdelrahim, M.; Cai, Q.; Truong, A.; Bick, R.; Poindexter, B.; Sheikh-Hamad, D. Stanniocalcin-1 suppresses superoxide generation in macrophages through induction of mitochondrial UCP2. J. Leukoc. Biol. 2009. [CrossRef] [PubMed]

60. Chakraborty, A.; Brooks, H.; Zhang, P.; Smith, W.; McReynolds, M.R.; Hoying, J.B.; Bick, R.; Truong, L.; Poindexter, B.; Lan, H.; et al. Stanniocalcin-1 regulates endothelial gene expression and modulates transendothelial migration of leukocytes. Am. J. Physiol. Ren. Physiol. 2007, 292, 895-904. [CrossRef]

61. Barnas, J.L.; Simpson-Abelson, M.R.; Yokota, S.J.; Kelleher, R.J.; Bankert, R.B. T cells and stromal fibroblasts in human tumor microenvironments represent potential therapeutic targets. Cancer Microenviron. 2010, 3, 29-47. [CrossRef]

62. Cohen, N.; Shani, O.; Raz, Y.; Sharon, Y.; Hoffman, D.; Abramovitz, L.; Erez, N. Fibroblasts drive an immunosuppressive and growth-promoting microenvironment in breast cancer via secretion of Chitinase 3-like 1. Oncogene 2017, 36, 4457-4468. [CrossRef] [PubMed]

63. Ruhland, M.K.; Loza, A.J.; Capietto, A.H.; Luo, X.; Knolhoff, B.L.; Flanagan, K.C.; Belt, B.A.; Alspach, E.; Leahy, K.; Luo, J.; et al. Stromal senescence establishes an immunosuppressive microenvironment that drives tumorigenesis. Nat. Commun. 2016, 7. [CrossRef] [PubMed]

64. Hosein, A.N.; Wu, M.; Arcand, S.L.; Lavallée, S.; Hébert, J.; Tonin, P.N.; Basik, M. Breast carcinoma-associated fibroblasts rarely contain p53 mutations or chromosomal aberrations. Cancer Res. 2010, 70, 5770-5777. [CrossRef]

65. Corver, W.E.; Haar, N.T.; Fleuren, G.J.; Oosting, J. Cervical carcinoma-associated fibroblasts are DNA diploid and do not show evidence for somatic genetic alterations. Cell. Oncol. 2011, 34, 553-563. [CrossRef] [PubMed]

66. Kang, N.; Shah, V.H.; Urrutia, R. Membrane-to-Nucleus Signals and Epigenetic Mechanisms for Myofibroblastic Activation and Desmoplastic Stroma: Potential Therapeutic Targets for Liver Metastasis? Physiol. Behav. 2015, 13, 604-612. [CrossRef] [PubMed]

67. Banerjee, J.; Mishra, R.; Li, X.; Ii, R.S.J.; Sharma, A.; Bhowmick, N.A. A reciprocal role of prostate cancer on stromal DNA damage. Oncogene 2013, 33, 4924-4931. [CrossRef]

68. Albrengues, J.; Bertero, T.; Grasset, E.; Bonan, S.; Maiel, M.; Bourget, I.; Philippe, C.; Herraiz Serrano, C.; Benamar, S.; Croce, O.; et al. Epigenetic switch drives the conversion of fibroblasts into proinvasive cancer-associated fibroblasts. Nat. Commun. 2015, 6. [CrossRef] [PubMed]

69. Mitra, A.K.; Zillhardt, M.; Hua, Y.; Tiwari, P.; Murmann, A.E.; Peter, M.E.; Lengyel, E. MicroRNAs reprogram normal fibroblasts into cancer-associated fibroblasts in ovarian cancer. Cancer Discov. 2012, 2, 1100-1108. [CrossRef]

70. Zhao, L.; Sun, Y.; Hou, Y.; Peng, Q.; Wang, L.; Luo, H.; Tang, X.; Zeng, Z.; Liu, M. MiRNA expression analysis of cancer-associated fibroblasts and normal fibroblasts in breast cancer. Int. J. Biochem. Cell Biol. 2012, 44, 2051-2059. [CrossRef]

71. Pereira, B.A.; Vennin, C.; Papanicolaou, M.; Chambers, C.R.; Herrmann, D.; Morton, J.P.; Cox, T.R.; Timpson, P. CAF Subpopulations: A New Reservoir of Stromal Targets in Pancreatic Cancer. Trends Cancer 2019, 5, 724-741. [CrossRef]

72. Lindner, T.; Loktev, A.; Giesel, F.; Kratochwil, C.; Altmann, A.; Haberkorn, U. Targeting of activated fibroblasts for imaging and therapy. EJNMMI Radiopharm. Chem. 2019, 4, 1-15. [CrossRef]

73. Ostermann, E.; Garin-Chesa, P.; Heider, K.H.; Kalat, M.; Lamche, H.; Puri, C.; Kerjaschki, D.; Rettig, W.J.; Adolf, G.R. Effective immunoconjugate therapy in cancer models targeting a serine protease of tumor fibroblasts. Clin. Cancer Res. 2008, 14, 4584-4592. [CrossRef]

74. Lo, A.; Wang, L.S.; Scholler, J.; Monslow, J.; Avery, D.; Newick, K.; Brien, S.O.; Evans, R.A.; Bajor, D.J.; Durham, A.C.; et al. Tumor-promoting desmoplasia is disrupted by depleting FAP- expressing stromal cells. Cancer Res. 2016, 75, 2800-2810. [CrossRef]

75. Lee, J.; Fassnacht, M.; Nair, S.; Boczkowski, D.; Gilboa, E. Tumor immunotherapy targeting fibroblast activation protein, a product expressed in tumor-associated fibroblasts. Cancer Res. 2005, 65, 11156-11163. [CrossRef] [PubMed] 
76. Gunderson, A.J.; Yamazaki, T.; McCarty, K.; Phillips, M.; Alice, A.; Bambina, S.; Zebertavage, L.; Friedman, D.; Cottam, B.; Newell, P.; et al. Blockade of fibroblast activation protein in combination with radiation treatment in murine models of pancreatic adenocarcinoma. PLoS ONE 2019, 14, e211117. [CrossRef] [PubMed]

77. Scott, A.M.; Wiseman, G.; Welt, S.; Adjei, A.; Lee, F.-T.; Hopkins, W.; Divgi, C.R.; Hanson, L.H.; Mitchell, P.; Gansen, D.N.; et al. A Phase I Dose-Escalation Study of Sibrotuzumab in Patients with Advanced or Metastatic Fibroblast Activation Protein-Positive Cancer 1. Clin. Cancer Res. 2003, 9, 1639-1647. [PubMed]

78. Roberts, E.W.; Deonarine, A.; Jones, J.O.; Denton, A.E.; Feig, C.; Lyons, S.K.; Espeli, M.; Kraman, M.; McKenna, B.; Wells, R.J.B.; et al. Depletion of stromal cells expressing fibroblast activation protein- $\alpha$ from skeletal muscle and bone marrow results in cachexia and anemia. J. Exp. Med. 2013, 210, 1137-1151. [CrossRef] [PubMed]

79. Feig, C.; Jones, J.O.; Kraman, M.; Wells, R.J.B.; Deonarine, A.; Chan, D.S.; Connell, C.M.; Roberts, E.W.; Zhao, Q.; Caballero, O.L.; et al. Targeting CXCL12 from FAP-expressing carcinoma-associated fibroblasts synergizes with anti-PD-L1 immunotherapy in pancreatic cancer. Proc. Natl. Acad. Sci. USA 2013, 110, 20212-20217. [CrossRef]

80. Pargellis, C.A.; Campbell, S.J.; Pav, S.; Graham, E.T.; Pitner, T.P. Inhibition of dipeptidyl peptidase IV (CD26) by peptide boronic acid dipeptides. J. Enzyme Inhib. 1997, 11, 151-169. [CrossRef]

81. Narra, K.; Mullins, S.R.; Lee, H.O.; Strzemkowski-Brun, B.; Magalong, K.; Christiansen, V.J.; McKee, P.A.; Egleston, B.; Cohen, S.J.; Weiner, L.M.; et al. Phase II trial of single agent Val-boroPro (Talabostat) inhibiting fibroblast activation protein in patients with metastatic colorectal cancer. Cancer Biol. Ther. 2007, 6, 1691-1699. [CrossRef]

82. Jansen, K.; De Winter, H.; Heirbaut, L.; Cheng, J.D.; Joossens, J.; Lambeir, A.M.; De Meester, I.; Augustyns, K.; Van Der Veken, P. Selective inhibitors of fibroblast activation protein (FAP) with a xanthine scaffold. Medchemcomm 2014, 5, 1700-1707. [CrossRef]

83. Ryabtsova, O.; Jansen, K.; Van Goethem, S.; Joossens, J.; Cheng, J.D.; Lambeir, A.M.; De Meester, I.; Augustyns, K.; Van Der Veken, P. Acylated Gly-(2-cyano)pyrrolidines as inhibitors of fibroblast activation protein (FAP) and the issue of FAP/prolyl oligopeptidase (PREP)-selectivity. Bioorganic Med. Chem. Lett. 2012, 22, 3412-3417. [CrossRef] [PubMed]

84. Jansen, K.; Heirbaut, L.; Verkerk, R.; Cheng, J.D.; Joossens, J.; Cos, P.; Maes, L.; Lambeir, A.M.; De Meester, I.; Augustyns, K.; et al. Extended structure-activity relationship and pharmacokinetic investigation of (4-quinolinoyl)glycyl-2-cyanopyrrolidine inhibitors of fibroblast activation protein (FAP). J. Med. Chem. 2014, 57, 3053-3074. [CrossRef]

85. Šimková, A.; Bušek, P.; Šedo, A.; Konvalinka, J. Molecular recognition of fibroblast activation protein for diagnostic and therapeutic applications. Biochim. Biophys. Acta Proteins Proteom. 2020, 1868, 140409. [CrossRef] [PubMed]

86. Kraman, M.; Bambrough, P.J.; Arnold, J.N.; Roberts, E.W.; Magiera, L.; Jones, J.O.; Gopinathan, A.; Tuveson, D.A.; Fearon, D.T. Suppression of Antitumor. Science 2010, 330, 827-830. [CrossRef]

87. Hirata, E.; Girotti, M.R.; Viros, A.; Hooper, S.; Spencer-Dene, B.; Matsuda, M.; Larkin, J.; Marais, R.; Sahai, E. Intravital imaging reveals how BRAF inhibition generates drug-tolerant microenvironments with high integrin $\beta 1 / F A K$ Signaling. Cancer Cell 2015, 27, 574-588. [CrossRef] [PubMed]

88. Su, S.; Chen, J.; Yao, H.; Liu, J.; Yu, S.; Lao, L.; Wang, M.; Luo, M.; Xing, Y.; Chen, F.; et al. CD10+GPR77+ Cancer-Associated Fibroblasts Promote Cancer Formation and Chemoresistance by Sustaining Cancer Stemness. Cell 2018, 172, 841-856.e16. [CrossRef]

89. Fiori, M.E.; Di Franco, S.; Villanova, L.; Bianca, P.; Stassi, G.; De Maria, R. Cancer-associated fibroblasts as abettors of tumor progression at the crossroads of EMT and therapy resistance. Mol. Cancer 2019, 18, 1-16. [CrossRef]

90. Mishra, R.; Haldar, S.; Placencio, V.; Madhav, A.; Rohena-Rivera, K.; Agarwal, P.; Duong, F.; Angara, B.; Tripathi, M.; Liu, Z.; et al. Stromal epigenetic alterations drive metabolic and neuroendocrine prostate cancer reprogramming. J. Clin. Investig. 2018, 128, 4472-4484. [CrossRef]

91. Jesnowski, R.; Fürst, D.; Ringel, J.; Chen, Y.; Schrödel, A.; Kleeff, J.; Kolb, A.; Schareck, W.D.; Löhr, M. Immortalization of pancreatic stellate cells as an in vitro model of pancreatic fibrosis: Deactivation is induced by matrigel and $\mathrm{N}$-acetylcysteine. Lab. Investig. 2005, 85, 1276-1291. [CrossRef]

92. Jacobetz, M.A.; Chan, D.S.; Neesse, A.; Bapiro, T.E.; Cook, N.; Frese, K.K.; Feig, C.; Nakagawa, T.; Caldwell, M.E.; Zecchini, H.I.; et al. Hyaluronan impairs vascular function and drug delivery in a mouse model of pancreatic cancer. Gut 2013, 62, 112-120. [CrossRef]

93. Melissari, M.T.; Chalkidi, N.; Sarris, M.E.; Koliaraki, V. Fibroblast Reprogramming in Gastrointestinal Cancer. Front. Cell Dev. Biol. 2020, 8, 1-9. [CrossRef] [PubMed]

94. Sherman, M.H.; Yu, R.T.; Engle, D.D.; Ding, N.; Atkins, A.R.; Collisson, E.A.; Connor, F.; Van Dyke, T.; Kozlov, S.; Tseng, T.W.; et al. Vitamin D Receptor-Mediated Stromal Reprogramming Suppresses Pancreatitis and Enhances Pancreatic Cancer Therapy. Cell 2015, 159, 80-93. [CrossRef] [PubMed]

95. Gorchs, L.; Ahmed, S.; Mayer, C.; Knauf, A.; Fernández Moro, C.; Svensson, M.; Heuchel, R.; Rangelova, E.; Bergman, P.; Kaipe, H. The vitamin $\mathrm{D}$ analogue calcipotriol promotes an anti-tumorigenic phenotype of human pancreatic CAFs but reduces $\mathrm{T}$ cell mediated immunity. Sci. Rep. 2020, 10, 17444. [CrossRef] [PubMed]

96. Calais, J. FAP: The next billion dollar nuclear theranostics target? J. Nucl. Med. 2020, 61, 163-165. [CrossRef]

97. Fischer, E.; Chaitanya, K.; Wuëst, T.; Wadle, A.; Scott, A.M.; Van Den Broek, M.; Schibli, R.; Bauer, S.; Renner, C. Radioimmunotherapy of fibroblast activation protein positive tumors by rapidly internalizing antibodies. Clin. Cancer Res. 2012, 18, 6208-6218. [CrossRef] 
98. Giesel, F.L.; Kratochwil, C.; Lindner, T.; Marschalek, M.M.; Loktev, A.; Lehnert, W.; Debus, J.; Jäger, D.; Flechsig, P.; Altmann, A.; et al. 68 Ga-FAPI PET/CT: Biodistribution and preliminary dosimetry estimate of 2 DOTA-containing FAP-targeting agents in patients with various cancers. J. Nucl. Med. 2019, 60, 386-392. [CrossRef]

99. Koerber, S.A.; Staudinger, F.; Kratochwil, C.; Adeberg, S.; Haefner, M.F.; Ungerechts, G.; Rathke, H.; Winter, E.; Lindner, T.; Syed, M.; et al. The Role of 68Ga-FAPI PET/CT for Patients with Malignancies of the Lower Gastrointestinal Tract: First Clinical Experience. J. Nucl. Med. 2020, 61, 1331-1336. [CrossRef]

100. Syed, M.; Flechsig, P.; Liermann, J.; Windisch, P.; Staudinger, F.; Akbaba, S.; Koerber, S.A.; Freudlsperger, C.; Plinkert, P.K.; Debus, J.; et al. Fibroblast activation protein inhibitor (FAPI) PET for diagnostics and advanced targeted radiotherapy in head and neck cancers. Eur. J. Nucl. Med. Mol. Imaging 2020, 47, 2836-2845. [CrossRef]

101. Watabe, T.; Liu, Y.; Kaneda-Nakashima, K.; Shirakami, Y.; Lindner, T.; Ooe, K.; Toyoshima, A.; Nagata, K.; Shimosegawa, E.; Haberkorn, U.; et al. Theranostics Targeting Fibroblast Activation Protein in the Tumor Stroma: 64Cu- and 225Ac-Labeled FAPI-04 in Pancreatic Cancer Xenograft Mouse Models. J. Nucl. Med. 2020, 61, 563-569. [CrossRef] [PubMed]

102. Toms, J.; Kogler, J.; Maschauer, S.; Daniel, C.; Schmidkonz, C.; Kuwert, T.; Prante, O. Targeting Fibroblast Activation Protein: Radiosynthesis and Preclinical Evaluation of an 18 F-labeled FAP Inhibitor. J. Nucl. Med. 2020. [CrossRef]

103. Kratochwil, C.; Flechsig, P.; Lindner, T.; Abderrahim, L.; Altmann, A.; Mier, W.; Adeberg, S.; Rathke, H.; Röhrich, M.; Winter, H.; et al. 68Ga-FAPI PET/CT: Tracer uptake in 28 different kinds of cancer. J. Nucl. Med. 2019, 60, 801-805. [CrossRef] [PubMed]

104. Lindner, T.; Altmann, A.; Krämer, S.; Kleist, C.; Loktev, A.; Kratochwil, C.; Giesel, F.; Mier, W.; Marme, F.; Debus, J.; et al. Design and Development of 99mTc-Labeled FAPI Tracers for SPECT Imaging and 188Re Therapy. J. Nucl. Med. 2020, 61, 1507-1513. [CrossRef] [PubMed]

105. Lindner, T.; Loktev, A.; Altmann, A.; Giesel, F.; Kratochwil, C.; Debus, J.; Jäger, D.; Mier, W.; Haberkorn, U. Development of quinoline-based theranostic ligands for the targeting of fibroblast activation protein. J. Nucl. Med. 2018, 59, 1415-1422. [CrossRef] [PubMed]

106. Loktev, A.; Lindner, T.; Burger, E.M.; Altmann, A.; Giesel, F.; Kratochwil, C.; Debus, J.; Marmé, F.; Jäger, D.; Mier, W.; et al. Development of fibroblast activation protein-targeted radiotracers with improved tumor retention. J. Nucl. Med. 2019, 60, 1421-1429. [CrossRef]

107. Loktev, A.; Lindner, T.; Mier, W.; Debus, J.; Altmann, A.; Jäger, D.; Giesel, F.; Kratochwil, C.; Barthe, P.; Roumestand, C.; et al. A tumor-imaging method targeting cancer-associated fibroblasts. J. Nucl. Med. 2018, 59, 1423-1429. [CrossRef] [PubMed]

108. Meyer, C.; Dahlbom, M.; Lindner, T.; Vauclin, S.; Mona, C.; Slavik, R.; Czernin, J.; Haberkorn, U.; Calais, J. Radiation Dosimetry and Biodistribution of 68Ga-FAPI-46 PET Imaging in Cancer Patients. J. Nucl. Med. 2020, 61, 1171-1177. [CrossRef]

109. Röhrich, M.; Loktev, A.; Wefers, A.K.; Altmann, A.; Paech, D.; Adeberg, S.; Windisch, P.; Hielscher, T.; Flechsig, P.; Floca, R.; et al. IDH-wildtype glioblastomas and grade III/IV IDH-mutant gliomas show elevated tracer uptake in fibroblast activation proteinspecific PET/CT. Eur. J. Nucl. Med. Mol. Imaging 2019, 46, 2569-2580. [CrossRef]

110. Shi, X.; Xing, H.; Yang, X.; Li, F.; Yao, S.; Zhang, H.; Zhao, H.; Hacker, M.; Huo, L.; Li, X. Fibroblast imaging of hepatic carcinoma with 68Ga-FAPI-04 PET/CT: A pilot study in patients with suspected hepatic nodules. Eur. J. Nucl. Med. Mol. Imaging 2020. [CrossRef]

111. Poeppel, T.D.; Binse, I.; Petersenn, S.; Lahner, H.; Schott, M.; Antoch, G.; Brandau, W.; Bockisch, A.; Boy, C. 68Ga-DOTATOC versus 68Ga-DOTATATE PET/CT in functional imaging of neuroendocrine tumors. J. Nucl. Med. 2011, 52, 1864-1870. [CrossRef]

112. Kurash, M.M.; Gill, R.; Khairulin, M.; Harbosh, H.; Keidar, Z. 68Ga-labeled PSMA-11 (68Ga-isoPROtrace-11) synthesized with ready to use kit: Normal biodistribution and uptake characteristics of tumour lesions. Sci. Rep. 2020, 10, 3109. [CrossRef]

113. Giesel, F.; Adeberg, S.; Syed, M.; Lindner, T.; Jimenez, L.D.; Mavriopoulou, E.; Staudinger, F.; Tonndorf-Martini, E.; Regnery, S.; Rieken, S.; et al. FAPI-74 PET/CT Using Either 18 F-AlF or Cold-kit 68 Ga-labeling: Biodistribution, Radiation Dosimetry and Tumor Delineation in Lung Cancer Patients. J. Nucl. Med. 2020. [CrossRef]

114. Chen, H.; Pang, Y.; Wu, J.; Zhao, L.; Hao, B.; Wu, J.; Wei, J.; Wu, S.; Zhao, L.; Luo, Z.; et al. Comparison of [68Ga]Ga-DOTA-FAPI-04 and $[18 \mathrm{~F}]$ FDG PET/CT for the diagnosis of primary and metastatic lesions in patients with various types of cancer. Eur. J. Nucl. Med. Mol. Imaging 2020, 47, 1820-1832. [CrossRef]

115. Imaging of Solid Tumors Using 68Ga-FAP-2286-Full Text View-ClinicalTrials.gov [Internet]. Available online: https:/ /www. clinicaltrials.gov/ct2/show /NCT04621435?term=FAP-2286\&draw=2\&rank=1 (accessed on 18 February 2021).

116. Hirmas, N.; Jadaan, R.; Al-Ibraheem, A. Peptide Receptor Radionuclide Therapy and the Treatment of Gastroentero-pancreatic Neuroendocrine Tumors: Current Findings and Future Perspectives. Nucl. Med. Mol. Imaging 2018, 52, 190-199. [CrossRef]

117. Wang, Y.; Weng, J.; Wen, X.; Hu, Y.; Ye, D. Recent advances in stimuli-responsive in situ self-assembly of small molecule probes for in vivo imaging of enzymatic activity. Biomater. Sci. 2021. [CrossRef]

118. De Decker, A.; Vliegen, G.; Van Rompaey, D.; Peeraer, A.; Bracke, A.; Verckist, L.; Jansen, K.; Geiss-Friedlander, R.; Augustyns, K.; De Winter, H.; et al. Novel Small Molecule-Derived, Highly Selective Substrates for Fibroblast Activation Protein (FAP). ACS Med. Chem. Lett. 2019, 10, 1173-1179. [CrossRef]

119. Wang, Q.; Guan, J.; Wan, J.; Li, Z. Disulfide based prodrugs for cancer therapy. RSC Adv. 2020, 10, 24397-24409. [CrossRef]

120. Giang, I.; Boland, E.L.; Poon, G.M.K. Prodrug applications for targeted cancer therapy. AAPS J. 2014, 16, 899-913. [CrossRef] [PubMed]

121. Kim, E.J.; Bhuniya, S.; Lee, H.; Kim, H.M.; Cheong, C.; Maiti, S.; Hong, K.S.; Kim, J.S. An activatable prodrug for the treatment of metastatic tumors. J. Am. Chem. Soc. 2014, 136, 13888-13894. [CrossRef] [PubMed] 